УдК 339.138

I. A. Абрамович,

к.е.н., дочент, доиент кафедри маркетингу,

Аніпровський державний аграрно-економічний університет

А. Ю. Ерименко,

студентка, Аніпровський державний аграрно-економічний університет

A. O. Вериева,

студентка, Аніпровський державний аграрно-економічний університет

DOI: $10.32702 / 2306-6814.2018 .21 .45$

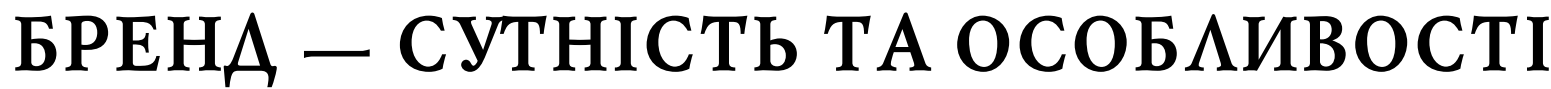 ЗАСТОСУВАННЯ В СІ $\Lambda$ ВЬКОМУ ГОСПОААРСТВI
}

\author{
I. Abramovich, \\ $\mathrm{PhD}$ in Economics, Associate Professor, Dnipro State Agrarian and Economic University \\ A. Efimenko, \\ student, Dnipro State Agrarian and Economic University \\ A. Vertseva, \\ student, Dnipro State Agrarian and Economic University
}

\section{BRAND-FEATURES OF APPLICATION IN AGRICULTURE}

Устатті проаналізовано сутність і особливості застосування бренду в сільському господарстві. Досліджено різні погляди науковців відносно визначення сутності поняття "бренд". Установлено, що бренд - це нематеріальний актив, цінність якого полягає у розпізнаванні його споживачами та формуванні позитивних асоціацій, пов'язаних з ним. Брендинг є ключовим і необхідним інструментом для успішного функціонування підприємства. Він може мати на увазі як створення нового бренду з нуля, так і вдосконалення існуючого бренду. Визначено, що за умов зростання конкуренції все більше уваги набуває активізація використання методики просування товару на ринок, зростання комунікативного впливу на цільові сегменти, збільшення арсеналу складових комплексу просування, за рахунок використання нестандартних методів маркетингових комунікацій. Оскільки ключовою метою бренду виступає створення єдиного образу мислення для групи споживачів, в якому мають бути всі важливі характеристики, які забезпечують його унікальність, а також максимальнукорисність, уході дослідження виокремлено складові елементи бренду.

The article analyzes the essence and features of the use of the brand in agriculture. Different views of scientists concerning the definition of the essence of the concept "brand" are researched. In recent years branding technology has come to Ukraine and has become widely used in the first place in the activities of multinational corporations that promote their mega brands, and then other commodity producers have been carefully looked at. The use of branding should also be used to develop the economic potential of agriculture in Ukraine, as domestic agricultural products should have access to the world market, and the brand should become one of the stages of realization of this goal. It is established that a brand is a non-material asset, the value of which is to recognize its consumers and to form positive associations associated with it. most authors describe the brand as a complex phenomenon that takes into account the material and intangible features of the brand's brand, this leads to the existence of a variety of approaches to the interpretation of the brand. Proceeding from the fact that all the proposed definitions explain the essence of the brand in the general sense, we consider it necessary to propose the definition of the essence of the concept of "brand" taking into account the characteristic features of agricultural commodity production. 
Consequently, the brand in agriculture is a special technology, namely, the organization of methods for processing, manufacturing, reformatting the state and characteristics of the image of the goods and the agricultural enterprise in general, taking into account the specificity of seasonality of the product. Branding is a key and necessary tool for the successful operation of the enterprise. It can mean both the creation of a new brand from scratch and the improvement of an existing brand. It is determined that in the conditions of increasing competition more and more attention becomes activated using the method of product promotion on the market, the growth of communicative influence on target segments, increase of the arsenal of components of the promotion complex, due to the use of non-standard methods of marketing communications.

Ключові слова: бренд, товар, сільське господарство, підприємство, методи, елементи, ефективність бренду.

Key words: brand, commodity, agriculture, enterprise, methods, elements, brand effectiveness.

\section{ПОСТАНОВКА ПРОБАЕМИ}

В останні роки технологія брендингу прийшла в Україну і широко стала використовуватися спочатку в діяльності транснаціональних корпорацій, що просувають свої мега бренди, а потім до неї стали уважно придивлятися і інші товаровиробники. Використання брендингу $є$ актуальним і для розвитку економічного потенціалу сільського господарства України, бо продукція вітчизняних сільськогосподарських підприємств повинна мати вихід на світовий ринок, а бренд має стати одним із етапів реалізації цієї мети. Умови жорсткої конкуренції змушують сільськогосподарські підприємства розробляти, освоювати і застосовувати різноманітні інструменти, що дозволяють отримати шанс у боротьбі за споживача. Наявність у підприємства унікальних активів і переваг, розвиненого менеджменту сприяють зміцненню позицій на ринку. Одним з таких активів підприємства $є$ бренд. Бренд - це нематеріальний актив, цінність якого полягає в розпізнаванні його споживачами та фрормуванні позитивних асоціацій, пов'язаних з ним. Брендинг є ключовим і необхідним інструментом для успішного функціонування сільськогосподарського підприємства. Він може мати на увазі як створення нового бренду з нуля, так і вдосконалення існуючого бренду.

Проблематика створення та просування бренду в сільському господарстві $є$ надзвичайно актуальною, адже в умовах сьогодення бренд здійснює значний вплив на ключові елементи ринкового механізму. Взаємовідносини з потенційними клієнтами встановлюються також за допомогою бренду. Бренд уособлює важливість товару чи послуги для споживача.

\section{АНААIЗ ОСТ АНHIX АОС $\Lambda$ АЖЕНЬ І ПУБАІКАЦІЙ}

Проблематику використання бренду в діяльності підприємства досліджували у своїх працях такі науковці: Д'Алессандро Д., Котлер Ф., Штовба О.В., Велещук С.С., Лисенко І.В., Капферер Ж.-Н., Парфренчук І.О., Мамлеева Л., Штовба О.В. та ін.

\section{ВИК ААА ОСНОВНОГО МАТЕРІААУ}

В умовах жорсткої конкуренції на ринку необхідність диференціювання свого продукту від продук- ту конкурентів призводить сільськогосподарського виробника до неминучості створення бренду. Споживачі купують відомі бренди, іноді навіть сплачуючи за них більшу ціну, тому що впевнені в їхній якості, прагнуть набути певного статусу або просто поділяють створену брендом фрілософрію. Поняття бренд виступає похідним словом від "brand", котре має значення "ставити клеймо". Таку назву мало тавро (клеймо), яким власники худоби позначали своїх тварин. 3 давніх часів клейма (бренду) були гідні лише високоякісні товари. Товар 3 клеймом виділявся серед аналогічних, набуваючи індивідуальності. Продукція з брендом завжди продавалася за вищою ціною, бренд додає родовому продукту (тобто продукту без бренду) додаткову цінність [1, с. 124].

Ключовими елементами у процесі створення бренду у сільському господарстві $\epsilon$ : реалізація маркетингових досліджень; розробка стратегії торгової марки; правильний вибір назви торгової марки, позиціонування і її спрямованість на визначений ринковий сегмент.

У сучасній економічній літературі не існує єдиного визначення сутності поняття "бренд", тому пропонуємо розглянути різні погляди науковців стосовно визначення цього терміну в таблиці 1.

Світова економічна криза стала наслідком погіршення ситуації на товарних ринках України, в результаті чого відбулося посилення потреби ефективнішого використання інструментів маркетингу для досягнення та утримання конкурентних переваг, а також зміцнення позицій сільськогосподарського підприємства на ринку в майбутньому. Отже, за умов зростання конкуренції все більше уваги набуває активізація використання методики просування товару на ринок, зростання комунікативного впливу на цільові сегменти, збільшення арсеналу складових комплексу просування, за рахунок використання нестандартних методів маркетингових комунікацій.

Аналізуючи вищенаведене важливо зауважити, що більшість авторів охарактеризовуючи бренд розуміють складне явище, котре враховує матеріальні і нематеріальні особливості об'єкта, якому належить бренд, це спонукає до існування різноманітних підходів стосовно тлумачення бренда. 
Таблиця 1. Визначення сутності поняття "Бренд"

\begin{tabular}{|l|l|}
\hline \multicolumn{1}{|c|}{ Автор } & \multicolumn{1}{|c|}{ Визначення } \\
\hline Ф. Котлер [2] & $\begin{array}{l}\text { Бренд - це обов'язок продавця надати покупцеві певний набір } \\
\text { властивостей товару, переваг та послуг, а також гарантії якості }\end{array}$ \\
\hline О. Штовба [3] & $\begin{array}{l}\text { Бренд - це цілісна сукупність товарного знаку та пов’язаних з ним } \\
\text { стійких знань, образів і асоціацій у споживачів з цільової аудиторії, } \\
\text { що збільшують обсяги реалізації продукції підприємства }\end{array}$ \\
\hline С. Велещук [4] & $\begin{array}{l}\text { Бренд - це сукупність характеристик товару (його атрибутів, уявлень } \\
\text { і знань споживачів про товар), елементів торгової марки (логотип, } \\
\text { назва та звуковий ряд) і товарного знака (юридичний захист) }\end{array}$ \\
\hline $\begin{array}{l}\text { ІВ. Лисенко, } \\
\text { А.Т. Кучер [5] }\end{array}$ & $\begin{array}{l}\text { Бренд - це інструмент, який дозволяє споживачу визначитись у } \\
\text { конкуренто напруженому ринковому середовищі й обрати «свій» } \\
\text { товар серед інших за допомогою упізнавання певних переваг } \\
\text { торгової марки }\end{array}$ \\
\hline $\begin{array}{l}\text { Ж.-Н. Капферер } \\
\text { [6] }\end{array}$ & $\begin{array}{l}\text { Бренд - це ексклюзивна концепція, яку поділяє та бажає більшість } \\
\text { людей, що втілена в товарах, послугах, місцях продажу і/або досвіді }\end{array}$ \\
\hline Д. Д’Алессандро \\
[1]
\end{tabular}

Джерело: сорормовано авторами на основі [1-6].

Виходячи з того, що всі запропоновані визначення пояснюють сутність бренда в загальному розумінні, вважаємо за необхідне запропонувати визначення сутності поняття "бренд" ураховуючи характерні особливості сільськогосподарського товаровиробництва. Отже, бренд у сільському господарстві - це особливі технології, а саме: організація методів обробки, виготовлення, переформатування стану і характеристик образу товару і сільськогосподарського підприємства вцілому, враховуючи специфіку сезонності товару.

Також бренд у сільському господарстві має здатність забезпечувати додаткові конкурентні переваги товарів та послуг, а також сільськогосподарського підприємства в цілому. За допомогою бренду, як додаткового інструменту конкурентоспроможності товари та послуги сільськогосподарського підприємства $є$ пізнаваними. В свою чергу зростає попит на брендовані товари та послуги, що дає змогу сільськогосподарському товаровиробнику отримати більший прибуток.
Парфренчук І.О. наголошує на тому, що сьогодні бренд є самим сильним інструментом бізнесу. Підприємствам необхідно створювати умови, за яких вироблена продукція була б якісна, потрібна споживачам, а ті обирали і купували саме ту продукцію, яка повністю задовольняла їх зростаючі потреби. Зміст ефективності брендингу можна розглядати в аспекті двох складових: комунікаційної та економічної. Отже, підприємства повинні сконцентрувати свої зусилля на фрормуванні сильних брендів, що вимагає від них застосування сучасних концепцій брендингу, їх адаптації до особливостей виробництва, впливу чинників внутрішнього і зовнішнього середовищ, які відрізняються мінливістю, інноваційністю та невизначеністю [7].

Ключовою метою бренду в сільському господарстві виступає створення єдиного образу мислення для групи споживачів, в якому мають бути всі важливі характеристики, які забезпечують його унікальність, а також максимальну корисність.

Складові бренду в сільському господарстві пропонуємо розглянути на рисунку 1.

Отже, удосконалюючи різноманітні погляди стосовно сутності та особливостей бренду в сільському господарстві, наголосимо на тому, що бренд виступає комплексом вражень, котрі залишаються у покупців у наслідок використання товару чи послуги.

Покликання бренду в сільському господарстві грунтується на тому, що він дає змогу вирішити такі завдання:

- здійснити ідентифікацію товару при згадуванні;

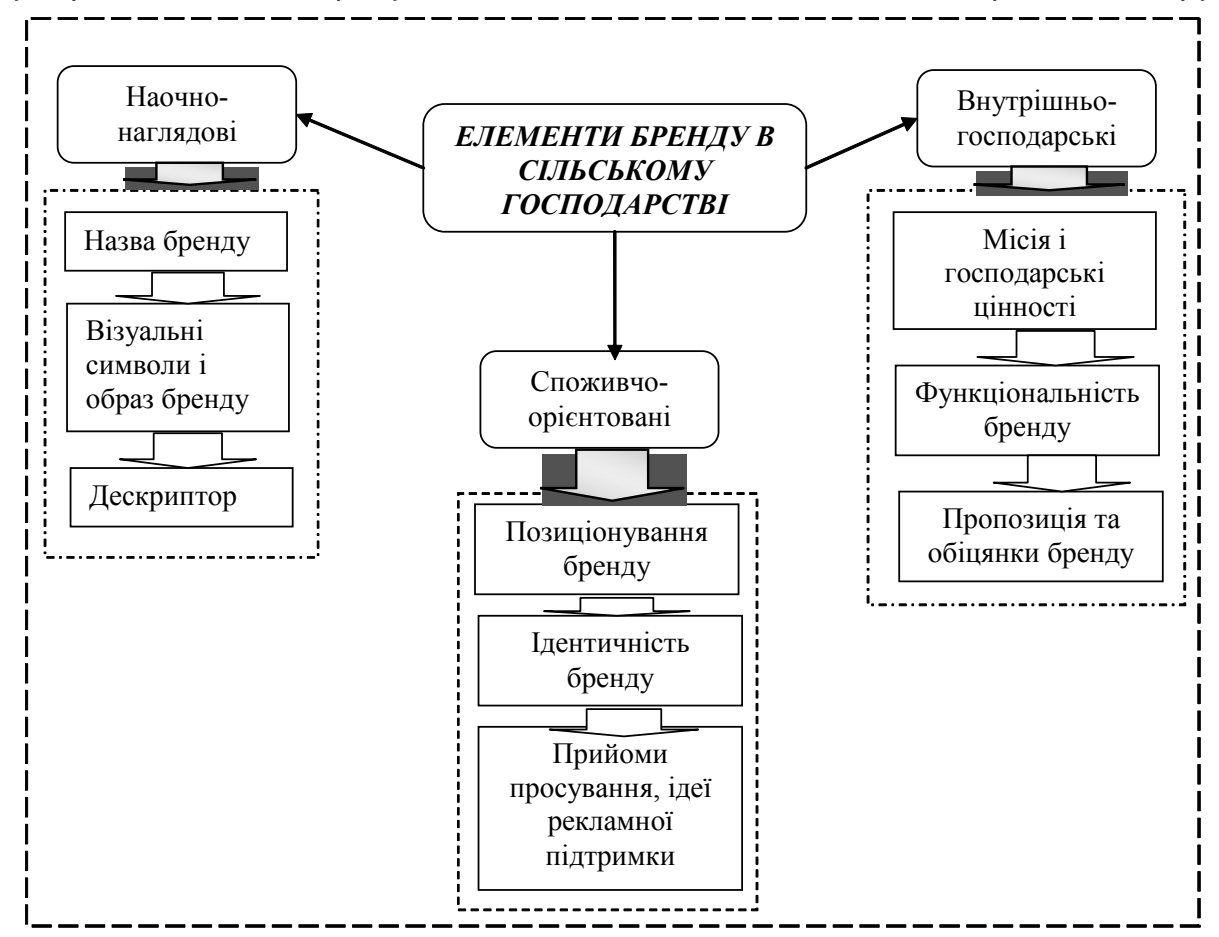

Рис. 1. Складові елементи бренду в сільському господарстві

Джерело: удосконалено авторами. 
- реалізувати у свідомості споживачів гарний образ, котрий викликає довіру;

- бути відмінним від конкурентів, а саме виділяти товар із загальної маси;

- генерувати позитивні емоції, пов'язані з товаром;

- приймати рішення стосовно покупки та отримати задоволення від прийнятого рішення;

- сорормувати групу постійних покупців, котрі асоціюють з брендом свій спосіб життя [8, с. 122].

Ключовою умовою індивідуальних особливостей бренду виступають ймовірні лише йому риси та відмінності від інших. Головними характеристиками бренду виступає:

a) Brand Essence - головний його зміст;

б) Brand Attributes - функціональні, а також емоційні зіставлення, котрі виражаються покупцями, а також потенційними клієнтами;

в) Brand Name - словесна складова марки або словесний товарний знак;

г) Brand Image - візуальний образ марки, сформований рекламою в увяві покупця;

д) Brand Power - доля популярності марки серед покупців, сила бренду;

e) Brand Identity - узагальнена сукупність ознак бренду, яка характеризує його індивідуальність;

ж) Brand Value - вартісні оцінки, показники;

з) Brand development Index - ступінь просунутості бренду;

и) Brand Loyalty - ступінь лояльності бренду у цільової аудиторії та її окремих сегментів [3, с. 11].

\section{ВИСНОВКИ І ПЕРСПЕКТИВИ ПОАААЬШИХ РОЗВІАОК}

Підсумовуючи результати проведеного дослідження зауважимо, що використання бренду в діяльност сільськогосподарських підприємств виступає достатньо вагомим фактором соціально-економічного розвитку. В ході господарської діяльності сільськогосподарських підприємств ключовою умовою результативності управління виступає ефективне його використання, котре грунтується на створенні брендом капіталу збільшення за допомогою унікальної ідентичності і сили бренда прибутковості сільськогосподарського підприємства.

Перспективами подальших досліджень, на нашу думку, $є$ створення окремих методик ефективності бренду сільськогосподарського підприємства та побудова розв'язок економіко-математичних моделей цієї ефективності, а також оцінка впливу бренду на розвиток сільськогосподарського підприємства.

Література:

1. Д'Алессандро Д. Войны брендов: 10 правил создания непобедимой торговой марки / Д. Д'Алессандро. - Петербург, 2002. - 224 с.

2. Котлер Ф. Маркетинг менеджмент / Ф. Котлер, К.Л. Келлер. - [12-е изд.]. - СПб.: Питер, 2006. - 816 с.

3. Штовба О.В. Товарний брендинг підприємств та шляхи забезпечення його ефективності : автореф. дис. на здобуття наук. ступеня канд. ек. наук : спец. 08.06.01 "Економіка, організація і управління підприємствами" / Штовба О.В. - Хмельницький, 2006. - 20 с.
4. Велещук С.С. Бренд-менеджмент в стратегічному розвитку підприємств: автореф. дис. на здобуття наук. ступеня канд. ек. наук: спец. 08.00.04 "Економіка та управління підприємствами" / Велещук С.С. - Київ, 2008. -20 c.

5. Лисенко І.В. Актуальність брендингу в Україні / І.В. Лисенко, А.Т. Кучер / / Матеріали Х-ої Міжнародної науково-практичної конференції студентів і молодих вчених "Економіка і маркетинг в умовах всесвітньої інтеграції: проблеми, досвід, передова думка". Том 1. - Донецьк: ДРУК - ІНФО, 2010. - С. 242-245.

6. Капферер Ж.-Н. Бренд навсегда: создание, развитие, поддержка ценности бренда / Ж.Н. Капферер - (Пер. $з$ англ. О.В. Виноградової; під заг. ред. В.Н. Домніна), 2007. - 448 с.

7. Парфенчук І.О. Методичні підходи до оцінки ефрективності бренду в системі національного господарства [Електронний ресурс] / І.О. Парфенчук / / Ефективна економіка: електронне наукове фахове видання. - 2016. - Вип. 4. - Режим доступу: http://www.economy.nayka.com.ua/?op $=1 \& z=5060$

8. Мамлеева Л. Анатомия бренда / Л. Мамлеева, В. Перция. - BrandAid, 2006. - 217 с.

\section{References:}

1. D'Alessandro, D. (2002) Vojny brendov: 10 pravil sozdanija nepobedimoj torgovoj marki [Brand wars: 10 rules for creating an invincible brand], St.Petersburg, Russia.

2. Kotler, F. and Keller, L. (2006) Marketing menedzhment [Marketing management], Piter, St.Petersburg, Russia.

3. Shtovba, O. V. (2006), "Commodity branding of enterprises and ways to ensure its efficiency", Ph.D. Thesis, Economics, organization and management of enterprises, Khmelnytskyi, Ukraine.

4. Veleshchuk, S. S. (2008), "Brand management in the strategic development of enterprises" Ph.D. Thesis, Economics and Enterprise Management, Kyiv, Ukraine.

5. Lysenko, I. V. and Kucher, A. T. (2010) "The relevance of branding in Ukraine", Materialy Kh-oi Mizhnarodnoi naukovo-praktychnoi konferentsii studentiv i molodykh vchenykh "Ekonomika i marketynh v umovakh vsesvitnoi intehratsii: problemy, dosvid, peredova dumka" [Materials of the Xth International Scientific and Practical Conference of Students and Young Scientists "Economics and Marketing in the Context of Global Integration: Problems, Experience, Advanced Thought"], PRINT - INFO, Donetsk, Ukraine, pp. 242-245.

6. Kapferer, Zh.- N. (2007) Brend navsegda: sozdanie, razvitie, podderzhka cennosti Brenda [Brand forever: Creating, developing, supporting brand value], Vershina, Moscow, Russia.

7. Parfenchuk, I.O. (2016), "Methodological approaches to the assessment of brand effectiveness in the system of national economy" Efektyvna ekonomika: elektronne naukove fakhove vydannia vol. 4 available at: http://www.economy.nayka.com.ua/?op=1\&z=5060 (Accessed 15 Oct 2018).

8. Mamleeva L., Percija V. (2006) Anatomija Brenda [Brand anatomy], Vershina, Moscow, Russia.

Cтаття надійила до редакиї 21.10.2018 p. 